\title{
Effect of spa therapy after intervertebral disc surgery in the cervical spine
}

\author{
Nechvatal $\mathrm{P}^{1}$, Takac $\mathrm{P}^{2}$, Stehlikova $\mathrm{B}^{3}$ \\ University of Presov in Presov, Faculty of Health Care, Department of Physiotherapy, Presov, Slovakia. \\ pavol.nechvatal@unipo.sk
}

\begin{abstract}
Objective: The aim of this paper is to determine whether standard spa treatment significantly affects disability, functional status, and quality of life of patients after surgery of intervertebral discs in the cervical spine. Material and methods: The study was performed in patients who underwent an artificial intervertebral disc replacement in the cervical spine.

The study involved a group of 88 patients with mean age of 49.49 (range 32 to 74 , standard deviation 9.12) while the experimental group consisted of 40 patients who underwent spa treatment with mean age of 49.35 (range 32 to 72 , standard deviation 7.69).

The control group was not treated by spa treatment, and consisted of 48 patients with mean age of 49.6 (range 36 to 74, standard deviation 8.73). These patients underwent standard medical rehabilitation at rehabilitation departments. Dysfunction of the cervical spine was scaled according to The Neck Disability Index (NDI).

Functional status of patients was evaluated by Pulses Profile, and quality of life was evaluated by test of the quality of life according to Spitzer.

Results: The statistical evaluation parameter for NDI, Pulses and Spitzer found significant difference at the significance level of 0.01 , suggesting that experimental group of patients who received spa treatment during follow-up examination had significantly better results in comparison with the control group.

Conclusion: As a result of this study we have concluded that after implantation of the artificial intervertebral disc replacement in the cervical spine it is appropriate to recommend spa treatment for its positive effect on disability, functional status, and quality of life (Tab. 3, Fig. 3, Ref. 24). Text in PDF www.elis.sk.

Key words: cervical spine surgery, intervertebral discs, spa treatment.
\end{abstract}

Development of civilization and respective technological progress brings new quality of life. On the other hand, a decrease in physical activity brings number of risk factors affecting the human body negatively. As a result of this, numerous mostly degenerative diseases of the musculoskeletal system, especially those of cervical spine are brought on $(1,2)$.

The spinal column is closely related to soft and vulnerable nervous system structures that can be damaged in various conditions of the motor segment of spine. For this reason, neck pain can be associated with root pain which radiates into the upper extremities and head and brings on vegetative symptoms associated with neck movement. The cause of these symptoms may lie in anatomical change. Cervical radiculitis affects approximately 83 per 100,000 of the population each year (3). Except intervertebral disc herniation it can be caused by osteoproductive changes in vertebrae, degenerative changes in joints, etc.

${ }^{1}$ University of Presov in Presov, Faculty of Health Care, Department of Physiotherapy, ${ }^{2}$ LF UPJŠ, Kosice, Department of Physical and Rehabilitation Medicine, and ${ }^{3}$ Technical University of Kosice, Faculty of Mining, Ecology, Process Control and Geotechnology, Institute of Control and Informatization of Production Processes, Kosice, Slovakia

Address for correspondence: P. Nechvatal, University of Presov in Presov, Faculty of Health Care, Department of Physiotherapy, Partizanska 1, SK08001 Presov, Slovakia.

Phone: +421.51 .7562495$
Although the success of conservative treatment of discogenic diseases is high (4), not all of them can be treated with positive results.

In this situation, surgery is indicated. Some authors have established (5) that surgical treatment is indicated approximately in $25 \%$ of patients with degenerative cervical spine disease. Since 1950's (Cloward, Robinson, Smith) $(6,7,8)$, the standard surgical procedure for herniated intervertebral disc in cervical spine used to be the anterior one established in various modifications.

At present time, in the spinal surgery, interbody spacers and cages are most commonly used (Carbon, PEEK, Cespace et al.). They keep suitable anatomical conditions and provide good conditions for the formation of solid bone fusion (9).

Semidynamic or dynamic intervertebral disc replacements are contraindicated once massive degenerative changes in facet joints are developed (10).

After surgery, the pain and clinical signs of radicular irritation subside and give the patients significant relief from symptoms. In spite of that, about $20 \%$ of patients are not completely satisfied with the postoperative overall results $(11,12)$ because of persisting difficulties.

Functional pathology of the musculoskeletal system in the cervical spine segments tends to be responsible for their unmet expectations. The operation solves the morphological aspects of 
the problem, but not the functional one. Functional pathology of the musculoskeletal system is dealt by physiatrics.

\section{Spa treatment}

In some European countries, spa treatment is not fully recognized as a separate medical specialisation. Firstly, there is a lack of scientific evidence, secondly, balneotherapy and climatotherapy are not used in all countries, and thirdly, the spa treatment is focused only on single methods that do not have a comprehensive concept. Other concerns are related to the facts that spa treatment can be performed only in a particular area and that there is a trend in balneotherapy conceived as wellness activity (13).

Benefits of spa are therefore still under discussion. Despite this, its natural healing capacities (hot springs, mineral waters and peloids) are used for therapeutic purposes $(14,15)$.

Spa medicine includes all medical activities derived from the tradition of spas, which are based on scientific knowledge focused on prevention, health promotion, treatment and rehabilitation (13).

Due to complexity, various forms of physical therapy (thermotherapy, hydrotherapy, electrotherapy, massage) are used (15).

Effects of these practices are sustained by climatic conditions and sunlight. The effects of spa treatments are also important for other social and psychological factors such as social networking, leisure and cultural activities, but also for the implementation of various recreational and sports activities, pleasant climate and natural health-promoting environment. Spa treatment (balneotherapy) can be described as a nonspecific therapy by means of naturally occurring water, gas and peloids. With that, there are also special climatic and psychosomatic effects associated with temporary changes in family and work environment (16)

\section{Purpose of research}

The aim of our work was to find out the effect of spa treatment on cervical spine dysfunction, functional status, and quality of life in an experimental group of patients undergoing surgery of intervertebral disc in the cervical spine. These results were compared with those from tests in the control group of patients who did not have spa treatment after surgery.

\section{Characteristics of the sample}

A group of 88 patients ( 34 men and 54 women) with mean age of 49.49 (range 32 to 74 , standard deviation 9.12) underwent implantation of an artificial intervertebral disc replacement in the cervical area. The youngest was aged 32 years and the oldest was 74 .

The number of patients in different age categories is shown in Figure 1.

Fifty-six patients have had one segment and 32 patients have had two segments operated on (Fig. 2). The experimental group consisted of 40 patients who underwent spa treatment while their mean age was 49.35 (range 32 to 72 , standard deviation 7.69). The control group was not treated with spa procedures and consisted

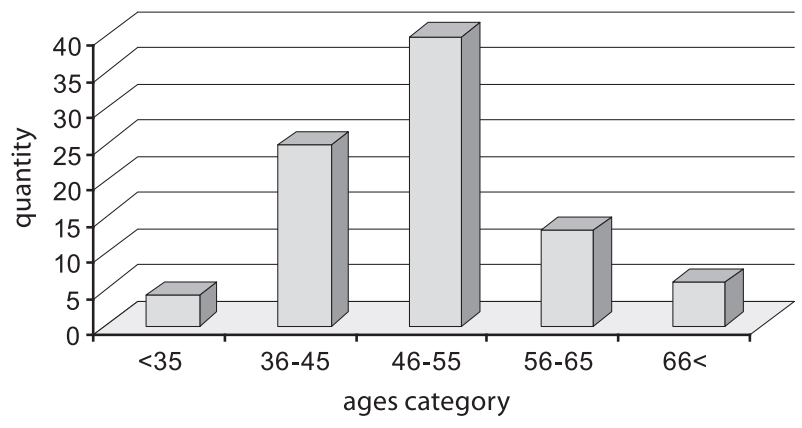

Fig. 1. Graphical scheme of patients in age categories.

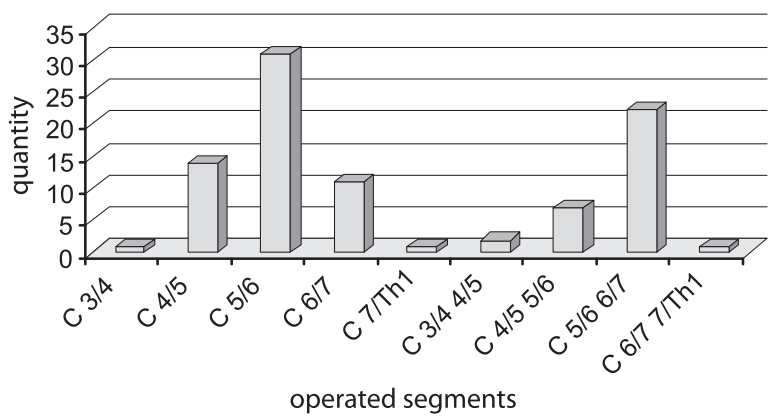

Fig. 2. Graphical scheme of operated parts of vertebrae.

of 48 patients with mean age of 49.6 (range 36 to 74 , standard deviation 8.73).

\section{Method of research}

The study was performed on patients who underwent implantation of an artificial intervertebral disc replacement in the cervical spine. Dysfunction in the cervical spine, functional status, and quality of life of patients was investigated before surgery and six months thereafter. During the six-month postoperative period, patients underwent medical rehabilitation at physiatric clinics and some of them absolved also spa treatment. Standard medical rehabilitation include light exercises and special techniques (post-isometric relaxation, soft techniques) aimed at correcting the muscle tension and length of the neck muscles, but have to be modified to take into account the post-operative conditions and limited mobility of the spine at the fusion site. Then there are fitness exercises of neck muscles performed in isometric manner. As part of practicing correct movement stereotypes it is needed to strengthen the muscles of shoulder blade fixators and lower blades. Light body massage and application of polarized light have positive impact on the state of muscles. Another appropriate way to support the healing process is magnetotherapy.

Dysfunction in the cervical spine in patients was evaluated by an international questionnaire according to The Neck Disability Index (NDI) (17). The questionnaire contains 10 parameters. They include pain intensity, personal care (washing, dressing, etc.), lifting, reading, headaches, concentration, work, driving, sleeping, and recreation. 
Tab. 1. The output outcome NDI questionnaire in patients after surgery of intervertebral discs in the cervical area.

\begin{tabular}{lccc}
\hline & $\begin{array}{c}\text { Experimental group } \\
\text { of patients }(\mathrm{n}=40)\end{array}$ & $\begin{array}{c}\text { Control group } \\
\text { of patients }(\mathrm{n}=48)\end{array}$ & $\mathrm{p}$ \\
\hline Pain intensity & $0.80 \pm 1.22(0-4)$ & $1.65 \pm 1.33(0-4)$ & 0.004 \\
Personal care & $0.22 \pm 0.48(0-2)$ & $0.73 \pm 0.89(0-3)$ & 0.013 \\
Lifting & $1.90 \pm 1.19(0-4)$ & $2.79 \pm 1.35(0-5)$ & 0.003 \\
Reading & $0.87 \pm 1.11(0-3)$ & $1.46 \pm 1.29(0-4)$ & 0.035 \\
Headaches & $0.90 \pm 1.21(0-4)$ & $1.33 \pm 1.33(0-4)$ & 0.125 \\
Concentration & $0.20 \pm 0.56(0-2)$ & $0.42 \pm 0.61(0-2)$ & 0.091 \\
Concentration & $1.17 \pm 1.24(0-4)$ & $2.17 \pm 1.29(0-5)$ & 0.001 \\
Driving & $0.70 \pm 0.88(0-3)$ & $1.25 \pm 1.31(0-5)$ & 0.081 \\
Sleeping & $0.65 \pm 0.95(0-4)$ & $1.23 \pm 0.97(0-3)$ & 0.004 \\
Recreation & $1.57 \pm 1.22(0-4)$ & $2.29 \pm 1.35(0-5)$ & 0.014 \\
\hline Total score & $8.97 \pm 7.85(0-27)$ & $15.31 \pm 8.50(1-28)$ & 0.001 \\
\hline
\end{tabular}

Tab. 2. The output outcome Pulses questionnaire in patients after surgery of intervertebral discs in the cervical area.

\begin{tabular}{lccc}
\hline & $\begin{array}{c}\text { Experimental } \\
\text { group of patients } \\
(\mathrm{n}=40)\end{array}$ & $\begin{array}{c}\text { Control group } \\
\text { of patients } \\
(\mathrm{n}=48)\end{array}$ & $\mathrm{p}$ \\
\hline Physical condition & $1.05 \pm 0.22(1-2)$ & $1.23 \pm 0.42(1-2)$ & 0.151 \\
Upper limb function & $1.22 \pm 0.42(1-2)$ & $1.77 \pm 0.51(1-3)$ & 0.000 \\
Lower limb function & $1.15 \pm 0.36(1-2)$ & $1.19 \pm 0.53(1-4)$ & 0.990 \\
Sensory components & $1.17 \pm 0.45(1-3)$ & $1.15 \pm 0.36(1-2)$ & 0.946 \\
Sxcretory functions & $1.02 \pm 0.16(1-2)$ & $1.08 \pm 0.28(1-2)$ & 0.642 \\
Support factors & $1.15 \pm 0.36(1-2)$ & $1.36 \pm 0.57(1-3)$ & 0.128 \\
\hline Total score & $6.77 \pm 1.14(6-11)$ & $7.79 \pm 1.57(6-12)$ & 0.001 \\
\hline
\end{tabular}

Tab. 3. The output outcome Spitzer questionnaire in patients after intervertebral disc surgery in the cervical area.

\begin{tabular}{lccc}
\hline & $\begin{array}{c}\text { Experimental group } \\
\text { of patients }(\mathrm{n}=40)\end{array}$ & $\begin{array}{c}\text { Control group } \\
\text { of patients }(\mathrm{n}=48)\end{array}$ & $\mathrm{p}$ \\
\hline Activity & $1.80 \pm 0.46(0-2)$ & $1.35 \pm 0.70(0-2)$ & 0.004 \\
Daily living & $1.97 \pm 0.16(1-2)$ & $1.87 \pm 0.33(1-2)$ & 0.419 \\
Health & $1.47 \pm 0.55(0-2)$ & $0.96 \pm 0.46(0-2)$ & 0.000 \\
Support & $1.92 \pm 0.35(0-2)$ & $1.96 \pm 0.20(1-2)$ & 0.943 \\
Outlook & $1.52 \pm 0.60(0-2)$ & $1.17 \pm 0.56(0-2)$ & 0.009 \\
\hline Total score & $9.72 \pm 1.22(6-10)$ & $8.46 \pm 1.44(5-10)$ & 0.000 \\
\hline
\end{tabular}

Each question has been scored $0-5$ points. Final score 0 points means minimal disability and 50 points the maximal one. We studied how pain in cervical spine affects the performance of various physical activities, as well as the intensity of pain.

Functional status of patients was evaluated by Pulses Profile (18). It quantifies indicators such as physical condition, upper limb function, lower limb function, sensory components, excretory functions and support factors. Each question has been scored with 1-4 points. Final score of 6 points means the maximal while 24 points mean the minimal functional ability of patient.

Quality of life was evaluated by the test of the quality of life according to Spitzer (19). It evaluates the activity, daily living, health, support and outlook. Each question has been scored with 0-2 points. The test reflects the quality of life while maximal score is 10 points and minimal one is 0 points.

The studied group of patients was divided into two groups according to whether they did or did not undergo spa treatment. The results of the tests studied in these groups were statistically processed and evaluated by means of the independent t-test, while the asymmetry and kurtosis coefficient had been calculated before.

Apart from observing the impact of spa treatment on disability, functional status, and quality of patient's life, the reasons, due to which some of the patients (control group) had not participated in spa treatment, were also investigated.

\section{Results}

By statistical data processing by means of T-test for total score of NDI parameter, we found statistical significance of $p-0.001$ (Tab. 1), for total score of Pulses parameter $\mathrm{p}-0.001$ (Tab. 2.) and the total score of parameter p Spitzer -0.000 (Tab. 3). Experimental group of patients exhibited significantly better results than the control group of patients in seven areas of NDI questionnaire, namely in pain intensity, personal care, lifting, reading, work, sleeping, and recreation. In the areas of headaches, concentration and driving, the results were not significantly different. In the Pulses questionnaire, the experimental group scored significantly better only in the area of upper limb function. In the areas of physical condition, lower limb function, sensory components, excretory functions, and support factors, the scores were not significantly different. In the Spitzer questionnaire, the experimental group displayed significantly better results in the areas of activity, health, and outlook. In the areas of daily living and support, there were no significant differences between the groups of patients.

When the experimental group of patients, who underwent spa treatment, was compared with the control group of patients who did not complete spa treatment, they exhibited a statistically significant improvement at the endpoint. The patients in the control

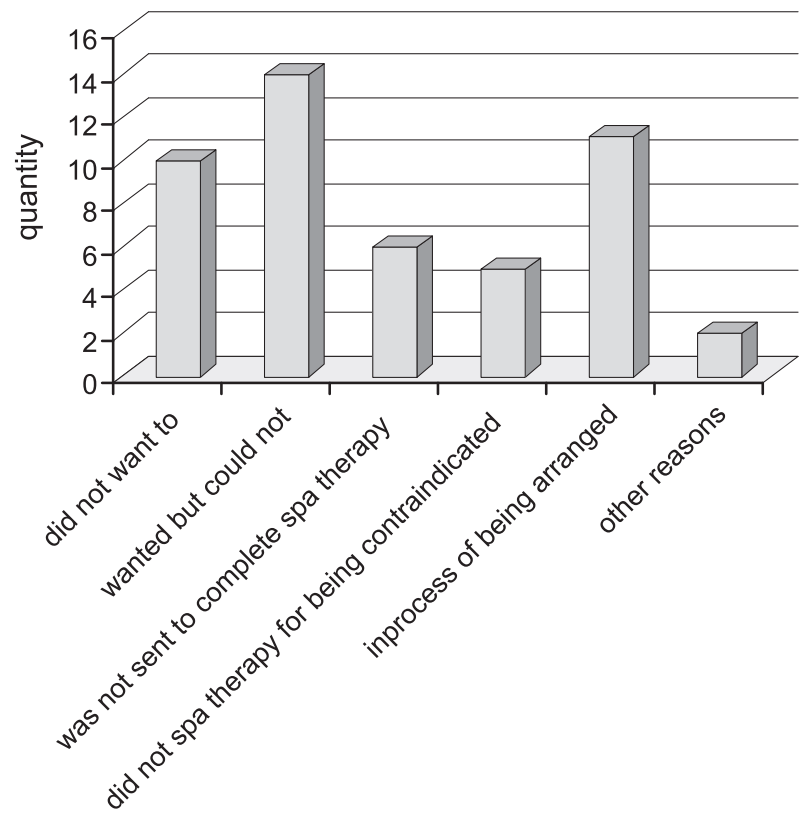

reasons not participated spa treatment

Fig. 3. Reasons of not completing spa therapy by patients. 
group did not undergo therapeutic spa treatment due to family or other reasons. Eleven patients were still awaiting a therapeutic spa treatment and some of them could not receive it because of contraindication (Fig. 3).

\section{Discussion}

Once the decompression extends the inter-vertebral disc, the patients usually experience relief from radicular symptoms. If the problem with the movement of the cervical spine continues, the subjective discomfort lasts too.

The goal of this study was to discover the effect of spa treatment for those who underwent the implantation with an artificial intervertebral disc replacement located in the cervical spine. Our results have shown that the physiotherapy plays a crucial role while spa therapy can assist by decreasing the individual's disability and increasing their functional status and quality of life. As the study results show, in addition to spa treatment, the functional disorders of the musculoskeletal system require also a physiatric treatment, which is ultimately reflected in greater reduction of disability and increase in functional status, which subsequently enhance the patients' quality of life.

Statistical processing of individual items of the NDI questionnaire revealed significantly better outcomes in the experimental group of patients in the areas quantifying the intensity of pain and describing how the pain affects performance of a variety of mobile activities (personal care, lifting, work, and recreation) as well as static activities (reading, sleeping). The items of the questionnaire that quantify headaches, concentration, and driving did not reveal significantly different results between experimental and control groups of patients.

A variety of mobile and static activities are provided by the musculoskeletal system. The musculoskeletal system is the most frequent source of pain in living organism (20). The healing effects of balneotherapy procedures and physical therapy are achieved by the influence of the afferent nervous system, while the increase or at least modification in the afferent stream of information into the central nervous system is achieved by the effect of certain stimulation of specific receptors (21). Because these receptors can be found not only in the skin but also in the tissue of the musculoskeletal system (21) they are available to the effects of the procedures of balneotherapy and physical therapy. This information is in correlation with the previously mentioned significantly better results in the experimental group of patients in the listed areas of NDI questionnaire.

The ongoing difficulties after the implantation of the artificial replacement of intervertebral disc in the cervical spine are of sensitive character and infrequently they are also exhibited through insignificant motor deficit in the area of the upper extremity. The procedures of balneotherapy and physical therapy modify nociceptive afferentation and generally have vasodilative, hyperaemic, trophotropic and stimulatory effects (21). This can explain the significantly better results in the experimental group in the areas of upper limb function in the Pulses questionnaire and in the test of the quality of life according to Spitzer, specifically in the areas where the outcome is directly affected by pain (activity, health and outlook). We did not note any significant differences in results in the areas of daily living and support.

A similar conclusion was reached in a study of Schmidt et al (22), where a sample of 14 patients with functional disorders of musculoskeletal system also confirmed the positive effect of complex spa treatment.

Schmidt et al (22) have shown a positive effect of spa therapy in their study composed of 14 patients with functional disorders of the musculoskeletal system.

On the other hand, the results of a randomized clinical study in which Forestier et al (23) compared the effects of spa therapy (44 patients) and pulsed electromagnetic field therapy in chronic neck pain (42 patients) suggest that chronic neck pain reacts better to pulsed magnetic field therapy. Interesting result came from Persson et al (24), who in their prospective randomized study compared the effects of surgical and non-surgical therapy (physiotherapy) in patients with chronic radicular pain in the cervical spine. There are no previous controlled outcome studies that have compared surgical treatment with nonsurgical treatment in patients with cervical radicular pain.

The study group comprised 81 patients with cervicobrachial pain, and the effect of treatment was evaluated by means of visual analogue scale pain. The therapeutic effects were evaluated by means of the visual analogue scale with respect to pain intensity. The first examination was done before treatment, when the measurement results were the same in all patients. Shortly after discontinuation, the second measurement was conducted in which patients treated surgically reported less frequent pain than patients undergoing physiotherapy. However, the authors (19) point out that in the long run, when the next 12-month check-up was done, it seemed that conservative and surgical treatment had been equally effective.

These different results (experience) in the treatment of discogenic disorders of the cervical spine show that in general it is a complex issue and that so far, there has not been a single profiled therapeutic approach. Much attention of professional public is given to different types of surgical procedures and artificial substitutes of cervical spine intervertebral discs.

There is not much evidence in Slovak or foreign scientific literature concerning post-surgery therapeutic procedures and patient management of this condition.

Therefore, it is possible to highlight here, that scientific research is needed to be carried out to verify and determine the most optimal treatment methods and procedures.

In light of the results of our study, there is an interesting analysis of the reasons for which patients after surgery of intervertebral discs in the cervical spine did not complete spa treatment (Fig. 3 ). More than one fifth of patients (10) did not want to receive spa treatment, because after surgical intervention, they felt well and did not consider it necessary. The follow-up examination of these patients achieved good outcomes (NDI, Pulses, Spitzer), yet it could not be seen in overall assessment, because the control group did not reach such a degree of reduction in disability, improved functional status and quality of life as compared to the 
experimental group. Worse results (higher rates of disability, lower participation rates, functional status, and quality of life) were probably reported because of those 25 patients (over half) who could not take spa treatment (for family and social reasons) as well as because of those, who at the time of the follow-up examination had not yet completed spa treatment.

\section{Conclusion}

Statistical evaluation of the results of control tests done six months after surgery confirmed (suggested) that spa therapy in patients after implantation of an artificial intervertebral disc replacement in the cervical spine has a significant therapeutic effect. It was manifested by less disability, greater functionality and quality of life in the experimental group of patients, and therefore we consider the indication of spa treatment in such conditions a necessity.

However, in our study, more than $50 \%$ of patients did not complete spa treatment, which we consider to be a negative fact that has a negative effect on health, as well as on socio-economic situation of the patient. There is therefore a need of greater cooperation of neurosurgeon, physiotherapist and general practitioner in motivating the patient to undergo spa treatments.

\section{References}

1. Meyer F, Börm W, Thomé C. Degenerative Cervical Spinal Stenosis - Current Strategies in Diagnosis and Treatment. Dtsch Arztebl Int 2008; 105 (20): 366-372.

2. Nikolaidis I, Fouyas IP, Sandercock PAG, Statham PF. Surgery for cervical radiculopathy or myelopathy. Cochrane Database of Systematic Reviews 2010, Issue 1. Art. No.: CD001466. DOI: 10.1002/14651858. CD001466.pub3 Assessed as up to date: December 15, 2008.

3. Huston CW. Cervical epidural steroid injections in the management of cervical radiculitis: Interlaminar versus transforaminal. A review. Curr Rev Musculoskelet Med 2009; 2: 30-42.

4. Hämmerle G. Die zervikale Diskushernie. Ars Med 2008; 20: 911-916.

5. Pataky F, Gajdoš M, Kat'uch V. Náhrady medzistavcových platničiek $\mathrm{v}$ liečbe degeneratívnych ochorení krčnej chrtice. Rozhledy v chirurgii 2010; 6: 336-343.

6. Botelho RV, Dos Santos Buscariolli Y, De Barros Vasconcelos Fernandes Serra MVF et al. The choice of the best surgery after single level anterior cervical spine discectomy: a systematic review. Open Orthop J 2012; 6: 121-128.

7. Dardis RM, ed. Inovations in anterior cervical spine surgery. 18331847. In Schmidek HH, Roberts DW. Operative neurosurgical techniques. Philadelphia; Saunders Elsevier, 2006.
8. Jerosch J, Steinleitner W. Minimal invasive Wirbelsäulen-Intervention. Köln; Ärtzte-Verlag GmbH, 2009: 417.

9. Barsa P, Pešánová $\mathbf{H}$, Suchomel P. Rehabilitační a režimové vedení pacientů po náhrade krční meziobratlové ploténky a intervertebrální déze. Rehab Fyz Lek 2004; 3: 122-127.

10. Korge A, Siepe ChJ, Heider F, Mayer HM. Zervikaler Bandscheibenersatz implantatspezifische Zugänge: Kielimplantat (Prodisc-C Bandscheibenprothese). Op Orthop und Traumatol 2010; 20 (5-6): 480-494.

11. Zoëga B, Kärrholm J, Lind B. Outcome scores in degenerative cervical disc surgery. Eur Spine J 2000; 9 (2): 137-143.

12. Faldini C, Chehrassan M, Miscione MT et al. Single-level anterior cervical discectomy and interbody fusion using PEEK anatomical cervical cage and allograft bone. J Orthop Traumatol 2011; 12 (4): 201-205.

13. Gutenbrunner C, Bender T, Cantista $\mathbf{P}$, Karagülle Z. A proposal for a worldwide definition of health resort medicine, balneology, medical hydrology and climatology. In: Int J Biometeorol 2010; 54 (5): 495-507.

14. Cimbiz A, Bayazit V, Hallaceli H, Cavlak U. The effect of combined therapy (spa and physical therapy) on pain in various chronic diseases. Complem Ther Med 2005; 13 (4): 244-250.

15. Rovenský J, Payer J, Clague RB et al. Dictionary of Rheumatic Disease. Wien: Springer Verlag, 2009, 23.

16. Heisel J, Jerosch J. Schmerztherapie der Halte- und Bewegungsorgane. Heidelberg; Springer Medizin Verlag 2007: 169-172.

17. Vernon HT, Mior SA. The Neck Disability Index: a study of reliability and validity. J Manip Physiol Ther 1991; 14: 409-415.

18. Granger CV, Albrecht GL, Hamilton BB. Outcome of comprehensive medical rehabilitation: Measurement by PULSES profile and the Barthel Index. Arch Phys Med Rehab 1979; 60: 145-154.

19. Spitzer W, Dobson A, Hall J. Measuring the quality of life of cancer patients: a concise QL-Index for use by physicians. J Chron Dis 1981; 34: 585-597.

20. Lewit K. Manipilační léčba v myoskeletální medicíně. Praha, Sdělovací technika, ve spolupráci s Českou lékařskou společností J.E.Purkyně, 2003: $17-20$

21. Poděbradský J, Poděbradská R. Fyzikální terapie. Praha: Grada Publishing, 2009: 17-18, 31-32.

22. Schmidt F, Gúth A, Hrdý J. Postura - jej zložky a ich terapeutické ovplyvnenie komplexnou kúpel'nou liečbou. Lek Obzor 2010; 7-8: 276-281.

23. Forestier R, Françon A, Saint-Arromand F. Are SPA therapy and pulsed electromagnetic field therapy effective for chronic neck pain? Randomised clinical trial First part: clinical evaluation. Annales de Réadaptation et de Médecine Physique 2007; 50: 140-147.

24. Persson LC, Carlsson CA, Carlsson JY. Long-term cervical radicular pain managed with surgery, physiotherapy, or cervical collar. A prospective, randomized study. Spine (Phila Pa 1976) 1997; 22: 751-758.

Received December 10, 2012. Accepted October 23, 2013. 